\title{
LEITURA EM AMBIENTES CÍBRIDOS: A COSMO(A)GONIA GEOMÉTRICA DE PATRICK BURGAUD
}

\author{
Luiz Antonio Garcia Diniz ${ }^{1}$ \\ Universidade Federal de São Carlos/LABI \\ luizdiniz953@yahoo.fr \\ Maria Heloisa Martins Dias \\ Livre docente em Literatura Portuguesa \\ mheloisa@ibilce.unesp.br
}

\begin{abstract}
Resumo: A cultura contemporânea vem nos mostrando, com uma evidência cada vez maior, que os campos do saber assim como as esferas de atuação se interpenetram intensamente, obrigando-nos a mudanças de comportamento no sentido de compactuar com as novas formas produtivas e criativas. Nosso escopo é considerar o ambiente cíbrido no qual situamos o leitor, nas suas relações com as produções poéticas criadas no universo digital, pelo viés de uma contextualização da leitura contemporânea realizada mediante interfaces e também pela leitura de um poema de Patrick Burgaud.
\end{abstract}

Palavras-chave: Leitura na Web, Sujeito cíbrido, Teoria da literatura, Patrick Burgaud, Ciberespaço

Abstract: Contemporary culture is showing us, with growing evidence, that fields of knowledge and spheres of action interpenetrate strongly, forcing us to change behavior in order to connive with the productive and creative new ways. Our scope is to consider the cybrid environment in which we situate the reader in his relations with the poetic productions created in the digital world, from the perspective of a contemporary context of reading done through interfaces and also by a reading of a poem by Patrick Burgaud.

Keywords: Reading on the Web, cybrid Subject, Theory of Literature, Patrick Burgaud, Cyberspace

\section{Introdução}

A cultura contemporânea vem nos mostrando, com uma evidência cada vez maior, que os campos do saber assim como as esferas de atuação se interpenetram intensamente, obrigando-nos a mudanças de comportamento no sentido de compactuar com as novas formas produtivas e criativas. Entre a

\footnotetext{
${ }^{1}$ Bolsista FAPESP - pós doutorado - LABI-UFSCar - supervisor: Adilson J A de Oliveira. 
literatura e a Internet, por exemplo, os canais têm se estreitado de tal forma que não é mais possível considerá-los isoladamente, o que nos coloca uma série de questionamentos acerca dos dois universos - inclusive o questionamento de suas divisões em espacialidades distintas e, em especial, no que se refere às linguagens em jogo e interações. Quando somos solicitados a refletir sobre leitura em mídias digitais, levamos em conta não somente a Internet como interface de leitura mas, igualmente, os suportes criados para este fim, como por exemplo, CDs, DVDs, instalações, enfim, o conjunto de mídias disponíveis para esse objetivo.

Não se trata mais de compreender a especificidade dos dois modos de produção, isto é, nem defender a literariedade ou singularidade da literatura, nem considerar a informatização tecnológica, considerada como o único meio/suporte cultural possível na contemporaneidade. Trata-se, antes, de reconhecer a abertura propiciada por esses dois veículos enquanto produtores de sentidos que só se configuram a partir das interações colocadas em jogo entre suas formas de construção e as relações estabelecidas com os receptores. Isto significa dizer que ambos, apesar da natureza própria de suas linguagens, convergem quanto aos efeitos gerados por seus procedimentos estruturais. Entre estes, podemos mencionar a desautomatização de condicionamentos e códigos instituídos, o dinamismo da percepção, novas configurações de espaço e tempo, o redimensionamento da noção de textualidade, o papel crítico-criativo do sujeito, o simultaneísmo dos gestos de escrita/produção/leitura, a importância dos geradores de texto, a proposta de novos paradigmas éticos e sociológicos e, no caso específico de nosso escopo, o repensar de estratégias de construção e de leituras.

Nesse sentido, discorrer sobre leitura em ambientes cíbridos significa ressituar - leitor na sua especificidade histórica, ou seja, o leitor na sua contemporaneidade. Assim, não podemos privilegiar uma reflexão unicamente voltada para as mídias digitais cujas particularidades podem conduzir a um determinado ambiente, um sistema construído com o objetivo de propiciar um ecossistema leitural, nem isolar o leitor como sujeito desvinculado de uma relação em contínua construção com esses mesmos ambientes e mídias com as quais ele se relaciona. Desse modo, abordar o sujeito cíbrido - enquanto Texto Digital, Florianópolis, v. 7, n. 2, jul./dez. 2011. ISSNe: 1807-9288 
agente construído e construtor dessa relação - implica pensar essa nova configuração do leitor investido de instâncias espaciais singulares.

Peter Anders ${ }^{2}$ considera o termo cíbrido como resultado de um hibridismo Cyber e Hybrid, termo até então conceituado somente do ponto de vista da cultura. Criado no ciberespaço e dotado de pelo menos dois fatores importantes, constitui-se no estar no ciberespaço ao mesmo tempo em que presencialmente, ou melhor, fisicamente, continuar no que consideramos como a instância material, ou seja, o que vulgarmente é considerado como o "real". Consideramos como um fato esse ser cíbrido, o que para nós se justifica, pois, afinal, sempre vivemos dois mundos: o material, determinado pelas contingências do cotidiano, e aquele do imaginário, propiciado pelas produções culturais sob as mais diversas formas, como entrada em um espaço privilegiado e absolutamente singular. Da mesma forma, devemos reconsiderar obviamente esse novo leitor na sua particularidade e, sobretudo, pensar a produção digital contemporânea sob novos paradigmas epistemológicos.

Tendo em vista esses elementos, ou seja, o apagamento de fronteiras estabelecidas entre o "real" e o "virtual", ou mesmo a substituição do signo real por atual, levaremos em conta esses aspectos na análise do poema de Patrick Burgaud $^{3}$ que faz parte do projeto Alpha: AVANT LE A L'HUMANITÉ N'EXISTAIT PAS, encontrado no endereço eletrônico http://arteonline.arq.br/a/p_a_trick_burgaud.html. Procederemos, assim, à análise do poema na sua proposta discursiva, ao mesmo tempo que atentaremos para os novos procedimentos construtivos com que o novo leitor se depara, ele mesmo sujeito às experiências que os espaços semióticos propõem. Antes de passarmos à análise, ou melhor, a uma leitura do texto poético de Burgaud, procederemos a uma breve contextualização do digital enquanto linguagem contemporânea pelo viés de alguns pensadores que refletiram sobre esse estatuto.

\footnotetext{
${ }^{2}$ http://www.deepdyve.com//p/sage/cybrids-integrating-cognitive-and-physical-space-inarchitecture-ddTIkkFLoz

${ }^{3}$ As obras digitais de Patrick Burgaud podem ser acessadas no endereço: http://aquoisarime.net/.
}

Texto Digital, Florianópolis, v. 7, n. 2, jul./dez. 2011. ISSNe: 1807-9288 
Vivemos hoje o resultado (POISSANT, 2007) da transição do material para o meio (mídia) e do meio para a interface. Tal configuração modifica, evidentemente, nossa posição, nosso estar no mundo, a partir do momento em que somente podemos estar em relação a algo. Esse algo são os meios pelos quais nos comunicamos ou recebemos a informação. Se a informação hoje é processada e comunicada por interfaces - no nosso caso específico, por interfaces construídas pelas tecnologias digitais - nos parece claro que nossa relação com a linguagem e com os objetos também mudou. A leitura de um livro, sua manipulação e o que condiciona seu uso enquanto objeto solicita uma determinada performatividade própria à cultura que esse objeto engendrou. Hoje, o artefato Leitor de textos, como os tablets e particularmente o Kindle, cria uma mobilidade física (wireless) que os primeiros computadores não permitiam. Então, o que notamos é uma agregação do artefato livro à tecnologia digital, uma simulação do impresso que pode ser até acentuada pelo brilho que o leitor de texto possibilita: algo semelhante à luz natural que emana de um texto impresso.

É interessante lembrar, como comentado por Vilém Flusser ${ }^{4}$ (2010), abordando a linearidade da leitura no suporte impresso: o modelo que gerou a escrita, metaforicamente, é o sulco:

a mão que escreve grava o sulco do plantio da semente, e o olho do leitor seleciona o grão maduro. Daí que "escrever" (scribere, graphein) significa originariamente "rasgar, gravar" e "ler" (legere, legein) signifiquem originariamente "selecionar".

É claro que a escrita criou outras dinâmicas e o próprio aspecto de sua hipertextualidade foi trazido à superfície com a incorporação das novas técnicas digitais: o acesso ao sugerido no texto analógico tornou-se matérico com o deslocamento do hipertexto para a Rede. Contextualizado no cibridismo em que a cultura contemporânea nos situa como sujeitos, a leitura processa-se tanto na seleção da informação disseminada na Rede, quanto na discursividade do objeto artístico. Ainda na trilha da reflexão de Flusser, a

FLUSSER, V. A Sociedade Alfanumérica. Disponível em: < http://www.cisc.org.br/html/uploads/a sociedade alfanumerica.pdf>. Acesso em: nov. 2010.

Texto Digital, Florianópolis, v. 7, n. 2, jul./dez. 2011. ISSNe: 1807-9288 
diferenciação operada pela leitura do texto literal e da alfanumérica pode ser resumida como se segue: na literal, os olhos vão seguindo uma linha, enquanto que, nas leituras geométricas ou aritméticas, os olhos se movem de modo circular (p. 7), conforme veremos mais abaixo na leitura do poema.

Segundo Steve Johnson (2001), o deslocamento do material para a interface evoluiu de uma maneira vertiginosa, por que - questão sempre recorrente nas ficções e figurativizadas na relação homem \& máquina - não projetarmos como devir algo que já é prática cotidiana? Se o sujeito do qual estamos falando é parte integrante de um espaço que não se situa mais na dicotomia material e atual (virtual), como situar a produção artística em uma das instâncias abordadas aqui? A reflexão sobre a leitura na Rede deve levar em conta esses dados. De um lado, a máquina semiótica produtora de novos espaços de significações e, de outro, o leitor, ele mesmo já modificado tecnologicamente pelos artefatos que a indústria digital lhe acena e por que não dizer, impõe a cada dia.

Desse modo, como delineia Louise Poissant (2007, p. 31), os princípios de conectividade, interatividade e imprevisibilidade dos comportamentos - aqui caberia situar os novos leitores - se afastam das velhas e distantes categorias filosóficas e dos modelos gregos de arte do suporte e dos objetos fechados. Poderíamos aventar, por esse viés, que, dentre inúmeras diferenças provocadas pelo deslocamento da leitura do impresso para a Internet, a centralidade do papel do leitor seja um dos elementos mais importantes no agenciamento da fluidez informacional das novas arquiteturas textuais.

Falar na centralidade do leitor não significa abandonar o objeto e sua construção. O objeto significa pela sua discursividade e por suas estratégias colocadas em jogo para que o leitor possa estabelecer uma relação. Tal relação não se reveste de um subjetivismo positivista do tipo cartesiano, uma vez que o olhar do leitor é direcionado por uma articulação sígnica proposta pelo objeto. Em outras palavras, a leitura, embora realizada pelo leitor, é conduzida pelo movimento proposto pelas estratégias discursivas enunciadas pelo objeto poético. 


\section{A Cosmo(a)gonia Geométrica de Patrick Burgaud}

Tendo em vista o panorama acima mencionado, ainda que brevemente, como acionarmos nossos dispositivos de leitura diante de uma composição como a de Patrick Burgaud? Aliás, não seria essa leitura um ato complexo, o qual intensifica nossa percepção ${ }^{5}$, impulsionando-a a desacomodar-se de automatismos condicionados para abrir-se a novas relações semióticas? Responder a tal questionamento implica exercitarmos esse ato semiótico, o que passaremos a realizar. A obra ${ }^{6}$ de Burgaud, ou melhor, o segmento que abordaremose faz parte do projeto Alpha; apresenta um pequeno texto, sob a forma verbal, e imagens, acompanhadas de som e movimento. Portanto, há diversas linguagens em diálogo e é justamente essa constelação de signos e os efeitos de sua produção simultânea de sentidos por meio de procedimentos singulares de construção o que nos cabe analisar.

Uma possível proposta pode partir do signo verbal:

\footnotetext{
${ }^{5}$ É sempre oportuno lembramos a famosa postulação chklovskiana a respeito do procedimento artístico em seu ensaio contido na obra Teoria da literatura: formalistas russos (1979). A duração da percepção ou sua resistência à imediatez no contato com o objeto artístico é o que nos leva a ver e não a reconhecer aquilo que perturba as convenções, desalojando-se do familiar. Conf. bibliografia.

${ }^{6} \mathrm{~A}$ título de esclarecimento queremos explicitar que o projeto Alpha é um conjunto de 365 poemas composto de 365 As, um para cada dia do ano. Trataremos aqui de um segmento proposto por Burgaud que na verdade realizou dois segmentos de segmentos que não procuram uma unidade, mas uma multiplicidade de singularidades ocorrendo no ciberespaço.
} 


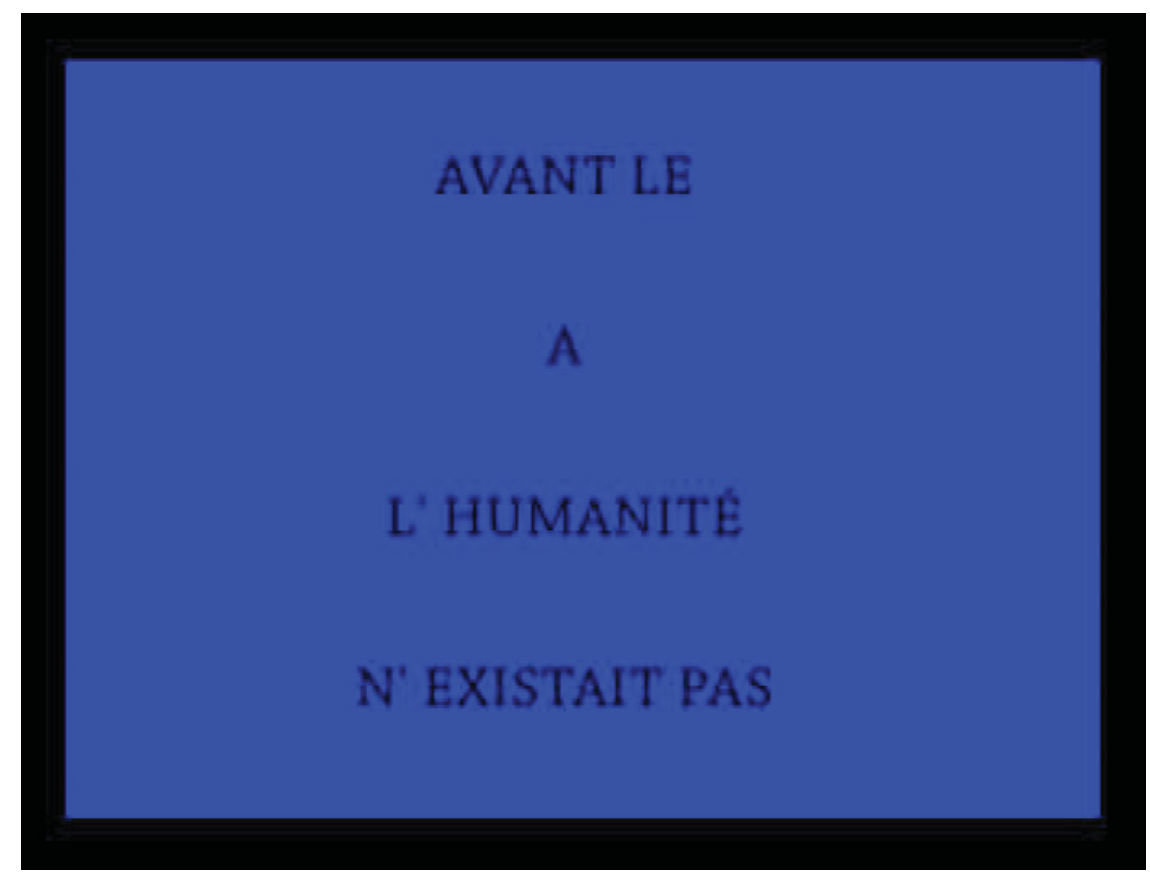

\section{AVANT LE \\ A \\ L'HUMANITÉ \\ N'EXISTAIT PAS}

Chama-nos atenção a incompletude do primeiro segmento verbal, de modo que o "LE" sem um nome que o defina abre-se a inúmeras possibilidades semânticas, porém, o que se destaca é o vazio virtualmente pleno contido nessa conjunção de ausência-presença, a qual estará atuando também na movimentação das imagens, como veremos. Já o segundo segmento, dividido espacialmente em dois momentos, contém um todo de significação - "a humanidade não existia" - que nos aponta para certo referente. $O$ alvo do olhar do poeta/artista se localiza, "definindo-se" como dimensão ampla, um universo sem existência a que, talvez, as imagens possam conferir concretude, reconfigurando-o.

No entanto, há um elemento perturbador nessa mensagem verbal: o "A" em meio ao texto (letra que sinaliza origem, início, Alpha, não por acaso o título do projeto) estaria propondo um suporte de sentido, uma baliza referencial? 
Estaria esse sinal gráfico completando o "LE" ou existiria como uma partícula isolada, um fragmento solto à espera de se reconfigurar por meio da união com outros elementos de um todo? Em outras palavras, seria esse "A" como $O$ triângulo que figura nos retângulos, isto é, uma peça só provisoriamente isolada, desconectada, que ganhará movimento e se unirá a outras?

$\mathrm{Na}$ verdade, estamos sendo levados pelo jogo instaurado pelo texto verbal, o qual suscita diversos questionamentos, e tal inquietação epistemológica é extremamente importante como gesto de leitura. Nesse círculo investigativo (hermenêutico), poderíamos continuar a levantar hipóteses: a preocupação com a não-existência da humanidade tem a ver com uma multiplicidade de fatores que o poeta elide ou prefere não apontar, assim como a questão da origem é um motivo caro à arte, mas que, no mundo contemporâneo, assume uma forma inusitada de expressão. Eis o que nos interessa.

Atentemos à configuração das imagens. À direita da tela, vemos oito retângulos dispostos 2 a 2, com o fundo em azul e com triângulos vermelhos que aumentam em quantidade até preencherem praticamente todo o retângulo: no primeiro retângulo há 2 triângulos, no segundo 4 , no terceiro 5 , no quarto 7 , no quinto 9 , até ficar difícil quantificarmos os triângulos, porque já borraram-se suas fronteiras. A partir de nossa interação com a composição, o movimento das imagens se faz à esquerda da tela, mostrando em detalhe o gradual preenchimento do retângulo com os triângulos vermelhos. 


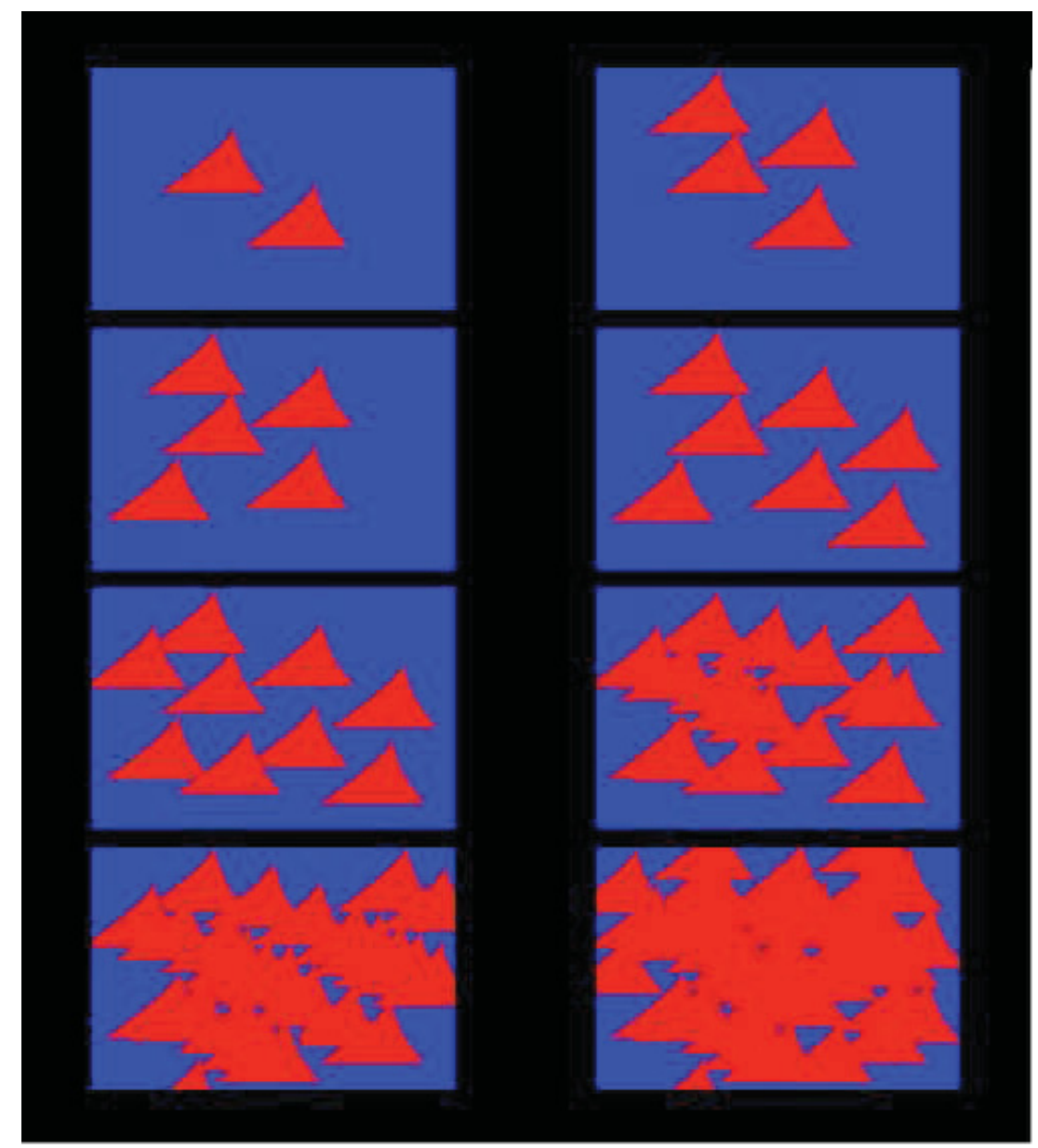

É flagrante o recurso ao geometrismo, o que se nota não apenas pela escolha das figuras (retângulos e triângulos) como também pelo princípio da gradação e sequencialização que vai tomando conta das imagens postas em movimento. Há, portanto, claramente, o fazer construtivo do poema gestando esse constructo artístico, revelando um percurso que vai do menos para o mais, da ausência para a presença, do vácuo para o cheio, do individual para o coletivo ou massificado. Pouco a pouco, os triângulos vão se dispondo de forma que o azul do fundo do triângulo desapareça sob a mancha vermelha que passa a ocupá-lo totalmente. E mais um dado a considerarmos: os triângulos perdem seu contorno específico em favor de uma massa vermelha.

Em relação à composição sonora, o que inicialmente ouvimos é algo como um balbucio ou jato gemido que, já no terceiro retângulo, se junta a outros sons de modo a se tornarem indistintos e irem se adensando coletivamente até se transformarem num alarido. Não são vozes, mas um chiado que se assemelha 
a uma locomotiva e sinetas. O efeito não é o de uma realidade harmônica ou melodiosa, e sim o de uma materialidade ruidosa em sua plena manifestação, porém, a cessar repentinamente ao final da composição. Também aqui, nos signos sonoros, notamos aquele percurso que vai do singular ao plural, do pouco ao muito, enfim, aquela progressão já comentada a propósito das imagens em seu movimento. Ou seja, há uma conjunção entre as diversas linguagens quanto ao procedimento formal utilizado, o que confirma o vetor do fazer construtivo de que falávamos, enquanto constitutivo desse projeto de Patrick Burgaud.

A essa altura é possível retomarmos alguns elementos para revelar as articulações tecidas entre as diversas linguagens dessa composição.

Se entendermos aquele "A" como o momento original (e originário), como o Alpha ou algo equivalente pois o signo não se encontra no corpo do texto, mas no título do projeto, não podemos deixar de associar a esse instante o ponto privilegiado a partir do qual a criação se dá. Mas uma criação que não se afirma como referente ou um dizer a apontar para a realidade extratextual, humana, histórica (ou bíblica?), e sim uma criação performática, que se funda sobre os signos que ela coloca em operação e em diálogo com o observador. Digamos que se trata de uma performance criadora que só passa a existir (lembremos o teor do texto verbal) porque acionada por imagens, cores, sons, movimentos que dão corpo e sentido a esse objeto. Nesse caso, podemos dizer que o texto que inaugura as imagens funciona como uma metalinguagem, na medida em que suas palavras anunciam e alertam para o próprio processo que a existência, não da humanidade, mas da composição sígnica, colocará em cena. É como se pudéssemos ler no texto o que ele não diz, mas deixa implícito: "ANTES DE (...) A HUMANIDADE NÃO EXISTIA, mas agora vou dar corpo e movimento a uma existência". Uma existência a qual o leitorobservador-internauta pode compartilhar, porque encontra-se imerso nas potencialidades materiais dos signos postos em ação.

Por outro lado, essa coisa que passa a existir graças à nossa interferência e desejo de com ela cumpliciar também solicita de nós uma visão mais ampla, que possa dar uma extensividade à metalinguagem. Assim, sabemos, por 
exemplo, que o vermelho simboliza vida, sangue, força, eros vital, daí o preenchimento do retângulo com essa cor que se torna, afinal, a realidade maior. Entretanto, associada aos ruídos que ouvimos enquanto os triângulos vão se alastrando, a cor vermelha pode despertar sentidos disfóricos, relacionados ao estalido estridente e continuado, como violência, agressão, até mesmo morte.

Da mesma forma que o sentido de humanidade, acoplado aos sons ruidosos, estaria desconstruindo os valores presentes no ideal daquele conceito (solidariedade, união, pluralidade, coletividade conjunção de diferenças, apagamento de fronteiras...) para sugerir valores opostos a esses. Afinal, o processo histórico nos tem mostrado o fosso que há entre a idealidade desejada para a existência humana e as contingências concretas que a desfiguram ou a tornam degradada. De qualquer modo, estamos diante de um universo gritante, tomado por uma coloração viva, cálida, que ocupa toda a área antes azul.

É interessante pensarmos, também, na escolha da forma geométrica. Por que triângulos? Nas anotações simbólicas referentes a conceitos de Filosofia, o triângulo costuma representar o indivíduo, o ser humano, o que nos remete às imagens móveis da obra de Burgaud. Explorando o conceito de humanidade, mas tratando-o como abstração, um signo poético, Burgaud coloca em sua obra sujeitos ou indivíduos estilizados, que adquirem forma geométrica, pois não é a individualidade ou especificidade pessoal que conta e sim a figura que os representa. Poderíamos pensar se essa não singularização humana, sugerida pela figura geométrica, não estaria construindo o sentido da desauratização da pessoa, imersa numa massa indistinta e reprodutora de estereótipos, própria da cultura pós-moderna. Porém, esta seria uma discussão para outro momento; fica aqui apenas sua sugestão.

Outro ponto a ser discutido é a mistura indistinta de sons criada em conjunção com as imagens. A partir da incitação sonora, podemos ponderar se esses ruídos são produzidos pelas próprias figuras triangulares que proliferam e se sobrepõem, portanto, são uma manifestação de sua presença, ou, ao contrário, se são eles os provocadores da multiplicação das figuras, as quais se 
aglomeram para fazer frente ao ruído crescente. Seja como for (e não cabe a um único receptor determinar ou estabelecer cabalmente os sentidos), o que interessa é exatamente essa ambiguidade suscitada pela mensagem poética de Burgaud.

A progressão das figuras vermelhas e sua sobreposição massiva figurativizam a superpopulação ou configuração global, característica de nosso tempo, mas é sempre oportuno lembrar que tal relação comporta uma duplicidade semântica: esse acúmulo crescente não significa apenas prejuízos e perdas, porque sua natureza problemática é sinal de que é preciso lidarmos com a heterogeneidade e complexidade da existência, feita de elementos tensos, contraditórios. Ganhos e perdas, plenitude e vazio.

O vazio, categoria visível nos espaços ainda não preenchidos pelos triângulos que proliferam, também se presentifica quando terminamos de operar com 0 constructo de Burgaud e voltamos ao início. Aí, sim, aquela noção de origem ou princípio destituído de humanidade fica patente. É preciso recomeçarmos o jogo, voltarmos a acionar a mecânica que sustenta a peça engenhada por Patrick: "antes do (...)". Estaria aí sugerido o mito do eterno retorno? Talvez, se ressignificarmos o sentido de mito ou o deslocarmos para o mundo contemporâneo, época marcada pela perda de crenças em valores absolutos, transcendentes. Faltos da inocência primitiva, somos impelidos a fabricar outros mitos, como seres e imagens digitais que dotamos de animação.

O texto de Burgaud nos convida, ademais, a pensar na noção de temporalidade, implícita na imagem de origem aludida pelas palavras. Que tempo seria esse "antes" de um "A" enigmático? De certa forma, nossa análise já tocou nesse ponto, ao identificarmos esse momento como o tempo próprio para a fundação/criação de algo, não importando quais seriam suas balizas ou referências. Tempo em que, tal como evidencia a poética de Mallarmé, o nada ou espaço em branco diz ou fala em contraste com a plenitude que o circunda; o que conta é explorar esse nada, fazendo suas virtualidades aflorarem à pele da página. O que conta é explorar as potencialidades ocultas na tela em que figura o objeto plástico-poético de Burgaud, colocando-as em ação. 
Todavia, podemos pensar em outra dimensão da temporalidade, a que diz respeito ao vínculo entre objeto e receptor. Nesse caso, o que conta é o tempo provisório, instantâneo, aquele que só existe enquanto dura a execução do projeto poético de Burgaud. Como toda produção digital, trata-se de uma presença que só encontra existência no acontecimento e na relação interativa, própria da imersão em realidades construídas por bits ${ }^{7} /$ bytes e na qual é solicitado o acionamento de dispositivos interativos. Sabemos que esse tempo é assim. Aceitamos o pacto com essa dimensão extremamente fugidia, mas ainda assim nela imergimos. Trata-se de algo semelhante ao que acontece com a suspensão da descrença (suspension of disbelief), de que falou Coleridge, a propósito de nossa relação com o mundo ficcional. A ilusão toma uma forma concreta, verdadeira, carregando-nos em seu bojo, fazendo submergirmos em seus riscos e aventuras - eis o poder da ficcionalidade, seja esta escrita clássica ou digital. Vivemos intensamente enquanto dura o (des)encanto; depois, é só fecharmos o livro ou a tela. Ou então, como na proposta de Burgaud, retomarmos a leitura (s) em looping indefinidamente.

\section{Poética na Internet}

Se nosso objetivo está relacionado com a leitura no espaço da Internet, cabe aqui abrir um parêntese para pensarmos nas relações que a nova poética, pois não se trata unicamente de uma mudança de espaço, mas sim de paradigmas do que significa poética, estabelece com a espacialidade.

Na poética contemporânea a máquina cumpre um papel fundamental e não podemos tomá-la unicamente como instrumento ou ferramenta. Ela se constitui em dispositivo produtor de signos tanto quanto a discursividade da poética criada pela obra e, desse modo, a consideraremos como um dispositivo criador de semioses. Como bem o ilustra Jorge Luiz Antonio (2010, p.22), " a assimilação do recurso tecnológico leva o poeta a intervir na própria tecnologia e na máquina para fazê-las produtoras de signos poéticos". A recorrência à máquina como interface e como forma de trazer à superfície a materialidade

\footnotetext{
${ }^{7} \mathrm{O}$ bit (BInary digiT) é a unidade mínima do código digital. Um conjunto de oito (oito) bits em unidades distintas forma um byte.
}

Texto Digital, Florianópolis, v. 7, n. 2, jul./dez. 2011. ISSNe: 1807-9288 
textual acentua a superposição de sentidos, a torna metalinguagem discorrendo sobre sua significação, uma espécie de tecido textual, que, acrescentando camada sobre camada, procura esconder um savoir-faire quase que perverso. As negociações semióticas com as tecnologias compreendem a mediação poeta-máquina por meio de signos e códigos e, igualmente, a intervenção do poeta na tecnologia computacional, tendo em vista sua estratégia poética e a relação clara que se estabelece entre sistemas, dito de outro modo, entre máquinas semióticas singulares e nas relações intersemióticas (p. 25-26). A visibilidade desse processo, ou seja, a sua materialidade em bytes transformada para a compreensão ou linguagem humana só ocorre nas interfaces. As interfaces ou o mundo-tela torna-se a mediação possível entre linguagens matemáticas e a poética contemporânea.

O trabalho de Steven Johnson Cultura da interface: como o computador transforma nossa maneira de criar e comunicar (2001), já citado anteriormente, elucida bastante os mecanismos de resistência culturais que levam gerações a rejeitarem as mídias digitais, a partir de experiências singulares. Ele historiciza, por assim dizer, todo um trajeto de informação tecnológica que em quinze anos mudou radicalmente nosso modo de existir e de interagir com o entorno. A idéia de espaço - informação existe desde os gregos, porém, só com sua realização física por meio do computador é que de uma escala individual tal espaço passou a ser construído por instâncias materiais no interior de uma sociedade global.

Tal materialidade, contrariamente ao senso comum, que divide o mundo em dois blocos, o virtual e o "real" ou material, é a responsável pela garantia da existência de um fluxo informacional incomensurável e que vem afetando nossa percepção e compreensão do mundo. Transportado para o universo da literatura e da poética digital, o deslocamento das mídias impressas para aquela construída por bits/bytes provocou inegavelmente uma reação que mobilizou teóricos, artistas e pesquisadores na tentativa de compreenderem os elementos que incidem sobre a mudança do estatuto do literário.

Há, ainda, aspectos importantes a serem abordados quando se trata da análise de objetos criados na tecnologia digital. Primeiro, há de se considerar a 
resistência dos já sedimentados pensamentos sobre a teoria literária ou, mais especificamente, sobre a especificidade do texto. Tal especificidade é estendida a todas as formas de texto conhecidas, como o fílmico, o fotográfico, o cinematográfico, entre outras formas de discursos voltados para os aspectos sonoros ou cromáticos. Arlindo Machado (2010) esclarece, em seu ensaio Arte e Mídia, como a confusão conceitual entre especificidades discursivas está ainda presente na nossa cultura, quando, afinal, a produção artísticotecnológica é basicamente produto tanto de hibridismos quanto de invasões e apagamentos das fronteiras defendidas pelos pensadores da "especificidade". A metáfora empregada pelo autor é uma conjunção de três círculos, cujas intersecções corresponderiam às relações estabelecidas entre os centros nucleares e suas bordas.

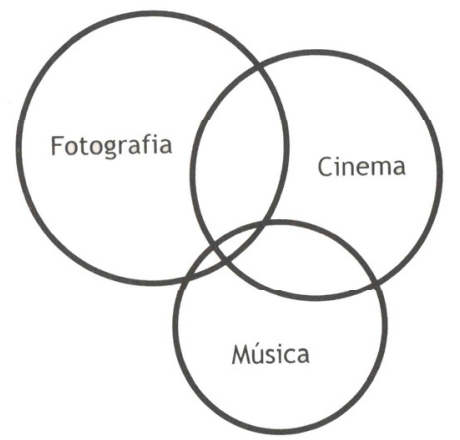

Figura 1: Diferentes áreas e suas intersecções Fonte: MACHADO, 2010, p.58.

$\mathrm{Na}$ ilustração acima, estariam representadas três áreas ou especificidades e, nas intersecções, a diluição ou integração de uma pela outra: a área de intersecção entre o cinema e a fotografia é maior, tendo em vista o material de produção comum às duas, a fotografia.

Ainda, segundo o autor, esse gráfico seria melhor representado na Figura 2: um núcleo mais escuro definindo as especificidades de cada área com uma gradação para o branco, espaço de cruzamentos, de interferências de uma especificidade sobre a outra. A relação entre o núcleo duro (mais escuro) para os espaços entre os estabelecidos nas intersecções seria na verdade a área 
em que as práticas se confundem e o que é "específico" deixa de ser, na medida em que os conceitos que o definem são deslocados para outros centros constituídos por outras práticas. Mesmo as funções relacionadas aos destinatários (público) podem ser as mesmas.

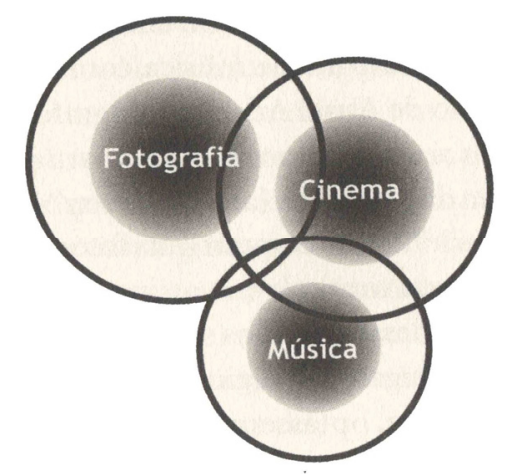

Figura 2: Especificidades de cada área e suas intersecções Fonte: MACHADO, 2010, p.60.

No gráfico a seguir, em uma visão tridimensional, vemos que os núcleos duros se superpõem e dão origem a conflitos relacionados a práticas, a conceitos e, sobretudo, existe uma nova ordem instaurada, movimento que poderíamos avançar como se constituindo na própria dinâmica da cultura nas suas relações com o fazer artístico.

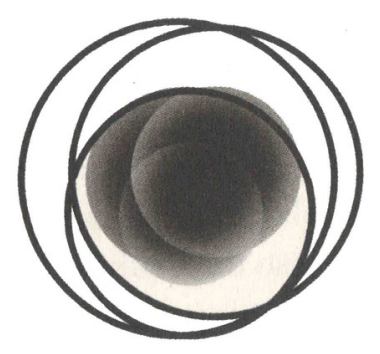

Figura 3: Visão tridimensional Fonte: MACHADO, 2010, p.65.

É nessa articulação que nos situamos e com a qual nosso trabalho procura dialogar. De um lado, procuramos contextualizar as mudanças paradigmáticas, epistemológicas, materiais e simbólicas e, de outro, criarmos condições para que a investigação teórica se posicione confrontada com esses novos objetos, 
os quais, afinal, sempre procuraram articular poética, narrativa e universos ficcionais. Tais universos, vinculados ou materializados mediante um suporte portador da informação, interessam justamente pelo modo como articulam os seus dados constitutivos, mesmo que o local de suas manifestações se dê em materialidades radicalmente diferentes das usuais, ou seja, daquelas originárias da herança do impresso, da estabilidade material dos signos, que data desde as escritas nas cavernas.

Nesse sentido, vale lembrar um artifício que acreditamos importante salientar: parece haver algo comum entre pensadores como Umberto Eco, Ezra Pound, Paz, Haroldo de Campos e outros tantos que abordaram o fenômeno poético, desde a teoria "clássica" às postulações mais modernas sobre o funcionamento do signo, por mais distintas que sejam suas terminologias, categorias conceituais e suportes utilizados. Para todos eles, os sentidos existem na espessura ou densidade indissolúvel da teia da linguagem, o que incita a percepção aguda do receptor.

\section{Referências}

ANDERS, P. Cybrids: Integrating Cognitive and Physical Space in Architecture. Disponível em: <http://www.deepdyve.com/lp/sage/cybrids-integratingcognitive-and-physical-space-in-architecture-ddTIkkFLoz>. Acesso em: 2007.

ANTONIO, J. L. Poesia digital: negociações com os processos digitais: teoria, história, antologias. São Paulo: Editora Navegar, 2010.

- Poesia hipermídia: estado de arte. In: RETTENMAIER, Guilherme; RÖSING, Tãnia (Orgs.). Questões de literatura na tela. Passo Fundo, RS: Editora UPF, 2010e, p. 123-149.

DOMINGUES, D. (Org.). Arte, ciência e tecnologia: passado, presente e desafios. São Paulo: Editora UNESP, 2007.

EIKHENBAUM, B. et al. Teoria da Literatura: formalistas russos. Porto Alegre: Globo, 1973.

FLUSSER, V. Sociedade Alfanumérica. Disponível em: $<$ http://www.cisc.org.br/html/uploads/a sociedade alfanumerica.pdf $>$. Acesso em: 2010. 
JOHNSON, S. Cultura da Interface: como o computador transforma nossa maneira de criar e comunicar. Trad. Maria Luiza X. De A. Borges. Rio de Janeiro: Zahar, 2001.

MACHADO, A. Arte e mídia. Rio de Janeiro: Zahar, 2010.

MATUCK, A.; ANTONIO, J. L. (Orgs.). Artemídia e cultura digital. São Paulo: Musa; PGEHA-USP; FAPESP, 2009.

POISSANT, L. In: DOMINGUES, D. (Org.). Arte, ciência e tecnologia: passado, presente e desafios. São Paulo: Editora UNESP, 2007.

RETTENMAIER, G.; RÖSING, T. (Orgs.). Questões de literatura na tela. Passo Fundo: Editora UPF, 2001. 